Reviews

policy. He regards economic development and conservation of tropical biodiversity as mutually exclusive goals, and in his discussion of sustainable development, economics is addressed as a main player in the fate of the Tropics. "The logic of economics is unassailable, but it is amoral" (p.156), he asserts. An entire chapter is devoted to arguing that tropical forests are unfortunately regarded as being "worth more dead than alive." He suggests that only from an anthropocentric view "wild nature and the biodiversity it perpetuates are not a necessity for humans; they are a luxury" (p.19). Taking this perspective as the dominant viewpoint, he argues that nature must be preserved for its own sake and not for its utilitarian value. His acceptance of this concept strengthens his argument in that it further illustrates his well-rounded approach to the problem of conservation in the Tropics.

Overall, Terborgh does a useful job of describing the current state of conservation in the Tropics. However, a slight shift in focus is called for: the book is long on problems, but short on solutions. The solutions that are presented are mainly at the sloganeering stage. Since these solutions are distinctive and appealing, I believe that he should describe more elaborately the solutions that he does present. Also, several additional solutions regarding other problems mentioned in Requiem should be included. Only then will we be able to gauge whether these ideas have the potential to bring about reform that is both significant and beneficial to the state of conservation in the Tropics.

\title{
Reference Cited:
}

Encarnation, Dennis J.

1995. "Regional Competition for Foreign Direct Investment? Asia and the Global Operations of Multinational Corporations." Pacific Basin Research Program, Kennedy School, Harvard University. Available

www.ap.harvard.edu/papers/RECOOP/Encarnation/FIAS.html

\section{Citizenship and Indigenous Australians: Changing Conceptions and Possibilities, edited by Nicolas Peterson and Will Sanders (1999). Cambridge, UK: Cambridge University Press, xiii + 222 pp.}

\section{Reviewed by Michèle D. Dominy, Department of Anthropology, Bard College, Annandale-On-Hudson, New York.}

In this tightly integrated collection, each author contributes to an understanding of the central tension articulated by editors Peterson and Sanders, who ask in their comprehensive introduction: "how can the descendants of precolonial indigenous Australians reconcile citizenship, with its emphasis on individual rights, with their surviving indigeneity in which loyalty to one's own people has primacy, especially within the contemporary nation state context where Australian aboriginal peoples assert indigenous rights and make demands for self-determination and land 
Reviews

restitution?"

In thinking about citizenship from the perspective of the multicultural present, the volume is concerned both with the surviving indigeneity of precolonial Australians and with the legacy of dispossession that advantages non-indigenous Australians. Peter Read characterizes this latter state of non-belonging as "the other side of the postcolonial coin" as he asks "can each accept the other as belonging in a legitimate but different way?" (p. 175). In this vein, at least two categories of citizens must reconceptualize citizenship at the close of the twentieth century. This sort of balanced refusal to oppositionalize and homogenize is one of the volume's strengths.

Another strength is the volume's long historical sweep. The first section traces the period of settlement to the nineteenth century in Margaret Wood's chapter, through the period of assimilation and welfare colonialism in chapters by Geoffrey Grey, Tim Rowse and Nicolas Peterson, to the 1967 Aboriginal Rights Referendum in Bain Attwood and Andrew Markus's piece, to the 1977 Community Development Employment Projects (CDEP) Scheme in Will Sander's contribution. In its second half, Citizenship and Indigenous Australians moves to detailed cases examining citizenship in the multicultural present. David Trigger examines Aboriginal responses to mining resource development, Garth Nettheim examines the role of international law in protecting indigenous rights, Henry Reynolds focuses on the concept of sovereignty, and Peter Read and Richard Mulgan ask difficult questions about the responsibilities of non-indigenous Australians in facing up to colonial dispossession and claiming responsibility in the present.

This historical scope points the attentive reader to the analytic potential for understanding changes in the liberal democratic state through a juxtaposition of the 1890s and the 1990s. The 1890 s and Federation mark the moment for a legally binding loss of rights at the state, territorial and federal levels. The Constitution of 1901 marks, according to Peterson, the high point of racism in Australia's colonial, post-, and neo-colonial histories. As Woods shows, the doctrine of terra nullius tightened in New South Wales, effectively denying either possession or economic use to its inhabitants, while indigenous sociocultural systems were systematically constituted and undermined through bureaucratic processes. By mid-century, assimilationist policies predominated. These are well-documented in Grey's sympathetic and yet critical analysis of A.P. Elkin's commitment to social justice as Elkin worked to "civilize" indigenous peoples and train them in self-reliance as a way of incorporating them into full and equal citizenship. The emphasis on equality and equal individual rights gave way to an emphasis on difference and group indigenous rights and separation in the 1970s (Sanders, p. 152); Sanders effectively documents and illustrates this shift in his case study of the CDEP Scheme. One hundred years later, Reynolds notes, Aboriginal and Torres Strait Islanders challenge federalism by turning to international forums as they seek the right to run their own affairs. Reynolds conceptually separates nation from state as he acknowledges that the state can contain multiple nations. And Mulgan suggests replacing reconciliation and consensus with accommodation and compromise as a strategy for creating a legitimate state for all of its diverse citizens.

Balanced and fine-grained historical and ethnographic analyses by Tim Rowse, Nicolas Peterson, and David Trigger reveal complex cultural entanglements and nuanced and overlapping articulations between and within these categories. Rowse and Peterson examine the cost of protectionist government policies for the integrity of the indigenous social order. Policies such as managed consumption simultaneously promoted a state of dependence and preserved the separation of indigenous social orders. On the other hand, the social rights accompanying citizenship, as in assimilation policy, have neocolonialist consequences; assimilation, for example, undermines Aboriginal unity and ends "colonial mechanisms of protection." In his analysis of the shift from rations to cash, from managed consumption to self-determination, Rowse explores the responsibilities inherent in indigenous citizenship, namely the responsibility for reproducing an indigenous social order (p. 79). Importantly, he asks, "how can the state promote collective forms of indigenous self-determination if indigenous people do not strive to reproduce their social forms and identity as a more or less officially recognized enclave within the Australian nation? (p. 80). Peterson criticizes the focus on political entitlement predominant in the concept of welfare 
Reviews

colonialism by arguing that such an approach simultaneously neglects the cultural and economic components of welfare colonialism as well as the reception of such entitlements by indigenous peoples. Subsuming economics to the political in this way diverts our attention from the material conditions of, and challenges in, daily life that result from the experience of being a "double citizen" in divergent cultural systems (p. 113). Through a discourse and practice approach Trigger argues similarly that citizenship is a "contested concept." Trigger examines Aboriginal peoples' attitudes to large scale mining resource development projects in the Gulf States. While acknowledging variations in responses, he is able to argue that aboriginal resistance to mining goes against predominant notions of citizenship that assert pro-development values and the productivity of land as essential for the national good. He concludes that "indigenous logics currently find expression in different common sense views about what should be done with land, what the rights and responsibilities of Aboriginal people should be, and what the dimensions of a fair 'trade' are with respect to the flow of benefits from large projects" (p. 163).

Writing clarity, the editors' carefully systematic sequencing of chapters, and the detailed substantive historical and case-based content of the separate chapters help the non-specialist reader to understand key concepts in political theory as they relate to citizenship and indigenous rights in Australia and beyond. These include: citizenship as it comprises civil, political and social rights; the relationship between nationalism and liberal political theory, assimilation and the contrasting concept of self-determination, federalism and its relationship to identity politics, sovereignty and its challenge to federalism, the sources of and interplay of international law with state based legislation, and multicultural citizenship in the nation state. Equally helpful for the non-Australian based reader is the overview that these chapters, taken collectively, provide of Australian Aboriginal and international human rights legislation. This includes, for example, the mutually reinforcing 1975 Racial Discrimination Act, the Mabo vs. Queensland 1992 native title decision, and the International Convention on the Elimination of All Forms of Racial Discrimination (1965) in Garth Nettheim's “The International Law Context.” Nettheim's discussion, like Mulgan's on the Council for Aboriginal Reconciliation, highlights the particular challenges to citizenship and its liberal democratic concerns for political and economic equality posed by indigenous rights demands for self-determination and land restitution. The theoretical influence of Will Kymlicka's multicultural commitment to "the accommodation of differences [as] the essence of true equality" (p. 27) is evident here and throughout the edited collection as it closes with his solution to the volume's guiding but unanswered question "how can people from different cultural and historical backgrounds be members of a common society on equal terms?" David Trigger's formulation of difference - with its potential for either nurturance or subordination - is similarly pertinent, and he presents the concept of "cultural citizenship" for encapsulated minorities as a way of resolving the tension between liberal ideals of citizenship and indigenous social orders for Aboriginal and Torres Strait Islanders. In this way, Trigger, like Rowse turns to an anthropological frame which allows for the possibility of an indigenous formulation of citizenship, one in which "the indigenous collectivity is a political scene with its own internal dynamics and tensions, its own philosophical issues of liberty and obligation" (Rowse, p. 97).

In its optimistic and uniform approach, the volume lacks perspectives that provide a deeply critical read of liberal multiculturalism (as formulated above by Kymlicka) and its relationship to the late modern democratic nation state and its technologies of power, such as shame and reconciliation. Whereas Citizenship and Indigenous Australians speaks to the possibility of reconciling citizenship with indigeneity, Elizabeth Povinelli in "The State of Shame: Australian Multiculturalism and the Crisis of Indigenous Citizenship" (Critical Inquiry 24[1998]:575-610) sees the "discourses, desires and imaginaries" of the nation and its subalterns as incommensurate. Alterity, she argues, should be a threat to national coherence rather than part of an incorporative project (p. 582). In this sense the volume is not successful in responding to Povinelli's challenge to unveil the ways in which the optimism of Australian multiculturalism works to "seduce critical thinking away from an analysis of how dominant social relations of 


\section{Reviews}

power rely on a multicultural imaginary and discourse in order to adjust core state institutions and narratives to new discursive, capital and state conditions, not to transform them (p. 583.). Her challenge converges with Trigger's and Rowse's suggestion for an indigenous formulation of citizenship, one that the volume's contributors do not articulate but suggest.

Mexican Rural Development and the Plumed Serpent: Technology and Maya Cosmology in the Tropical Forest of Campeche, Mexico, by Betty Bernice Faust (1998), Westport, CT: Bergin \& Garvey. xxviii, 190 pp. Reviewed by Edward F. Fischer, Department of Anthropology, Vanderbilt University.

\section{Middle Eastern Women and the Invisible Economy, Richard A. Lobban, Jr., editor (1998), Gainesville, FL: University Press of Florida. 303 pp.}

\section{Reviewed by Paula Holmes-Eber, Department of Anthropology and Middle East Center University of Washington, Seattle WA.}

Richard Lobban's edited volume, Middle Eastern Women and the Invisible Economy, presents a collection of fourteen articles on a critically important, yet regrettably, severely neglected topic in gender and Middle Eastern studies: the role of women in the informal, or invisible, economy. While studies of women's survival strategies and economic participation outside of the formal sector have burgeoned in other regions of the world, (see for example, Beneria and Roldan 1990; Collins and Gimenez 1990; Chant 1991 and Smith, Wallerstein and Evers 1984), research on Middle Eastern women's formal and informal economic activities has, until recently, been all but non-existent.

Historically and statistically, Middle Eastern women's participation in the formal labor force has lagged significantly behind all other regions of the world (Moghadam 1993). Muslim women's lack of visible participation in "public" and measurable economic arenas reinforces the perception that they are excluded from, and lack interest in economic affairs. Most research about women in the Middle East has thus tended to focus upon such topics as women's legal status, gender roles and ideals, or women and Islam, rather than examining women's actual economic, social and political behavior. Indeed, as Homa Hoodfar wryly observes, "It [is] as though Muslims, and in particular Middle Eastern people live in the realm of ideology and religion while the rest of the world live[s] within the economic structure" (1997: 15).

Hence, the articles in Lobban's book, split among four separate sections an "Strategies for survival: women at the marginsä; "Women and work: the invisible economy of Egyptä; "Methods and measures: the invisible economy of Tunisiaä; and "Locations and linkages in the invisible economyä offer a welcome and long overdue examination of the many creative ways that women in the Middle East earn, save and dispose of their own incomes, outside of the formal, measurable economic structure. As Early's, Lobban's, and Berry-Chickhaoui's articles illustrate, women often 